\title{
A Case Study on Relationships Between Psychological Capital, Personality and Organizational Commitment
}

\author{
Ebru Yildiz ${ }^{1}$ \\ ${ }^{1}$ Faculty of Economics and Administrative Sciences, Department of Business, Beykent University, Istanbul, Turkey \\ Correspondence: Ebru Yildiz, Faculty of Economics and Administrative Sciences, Department of Business, Beykent \\ University, Ayazaga-Maslak Campus, Sarıyer-Istanbul, Turkey.
}

Received: February 14, 2018

Accepted: March 5, 2018

Online Published: March 9, 2018

doi:10.5430/ijba.v9n2p99

URL: https://doi.org/10.5430/ijba.v9n2p99

\begin{abstract}
The aim of this study is to examine the effect of psychological capital and personality on organizational commitment. Furthermore, it was also aimed to examine the relationships between these two concepts because there is a small number of studies that reveal the relationships between psychological capital and personality characteristics. In this context, a full count was performed in a manufacturing enterprise, and the questionnaire study was conducted on a total of 217 people including all white and blue-collar employees. All employees were reached by face to face interviews. The collected data were analyzed by SPSS 21 and Lisrel 8.51.

The results of the study show that psychological capital positively affects affective, continuance and normative commitments. Similarly, personality characteristics also have a significant effect on organizational commitment. Extraversion, conscientiousness, agreeableness and openness to experience among personality characteristics positively affect the organizational commitment. It was observed that neuroticism had a positive effect on organizational commitment, contrary to expectations.

The relationships between the relevant two concepts affecting organizational commitment were also found significant. A positive relationship was found between psychological capital and conscientiousness, agreeableness and openness to experience while a negative and significant relationship was found between psychological capital and neuroticism. Contrary to expectations, a negative and significant relationship was achieved between psychological capital and extraversion.
\end{abstract}

Keywords: psychological capital, personality, five-factor personality model, organizational commitment

\section{Introduction}

The expectations of organizations from employees have been increasing along with the increasing global competition and other developments in business life in recent years. On the other hand, economic, social and technological developments also lead to the differentiation of the needs and expectations of employees. All these developments require organizations to focus more on employees as their most important resources.

In this context, this study examines the relationships between psychological capital, personality characteristics and organizational commitment, which are important in terms of organizational behaviour literature. The effect of psychological capital on employees' organizational commitment is an important issue for organizations. It is particularly important to be aware of the existence of employees' positive aspects, to develop these characteristics and to ensure that they use these characteristics in line with the purposes of the organization. The creation and maintenance of these possibilities also affect employees' organizational commitment positively.

Similarly, to ensure that employees with different personality characteristics work in line with the organizational purposes and in harmony and the fact that managers have the knowledge and skills to manage these differences also affect employees' organizational commitment positively.

However, there is a small number of studies that reveal the relationship between psychological capital and personality characteristics. From this aspect, this study has an original characteristic. Furthermore, it is observed that the studies carried out were generally on white-collar employees. The fact that the study involves a manufacturing enterprise and the employees, the vast majority of which consisted of blue-collar employees, is another important characteristic of the study. 
In this context, this study has a particular importance in terms of providing information that will contribute to the literature and practice by making determinations on how psychological capital and personality characteristics affect organizational commitment and on the relationship between psychological capital and personality characteristics in the light of research findings.

\section{Theoretical Framework}

\subsection{Psychological Capital}

Psychological capital is different from economic capital expressing "what we have", human capital expressing "what we know", and social capital expressing "who we know" and is a concept that is beyond these concepts. Psychological capital expresses who we are and what we can be in the developmental sense (Luthans, Luthans and Luthans, 2004: 46; Luthans, Youssef and Avolio, 2007: 20).

Psychological capital is an upper structure consisting of the combination of the concepts of self-efficacy, hope, optimism and resilience that best meet the criteria of positive organizational behaviour, which is the organizational dimension of positive psychology. As it can be seen in Figure 1, all of these components that constitute psychological capital best meet positive, unique, measurable, developable and performance-related criteria of positive organizational behaviour (Luthans and Youssef, 2004: 153).

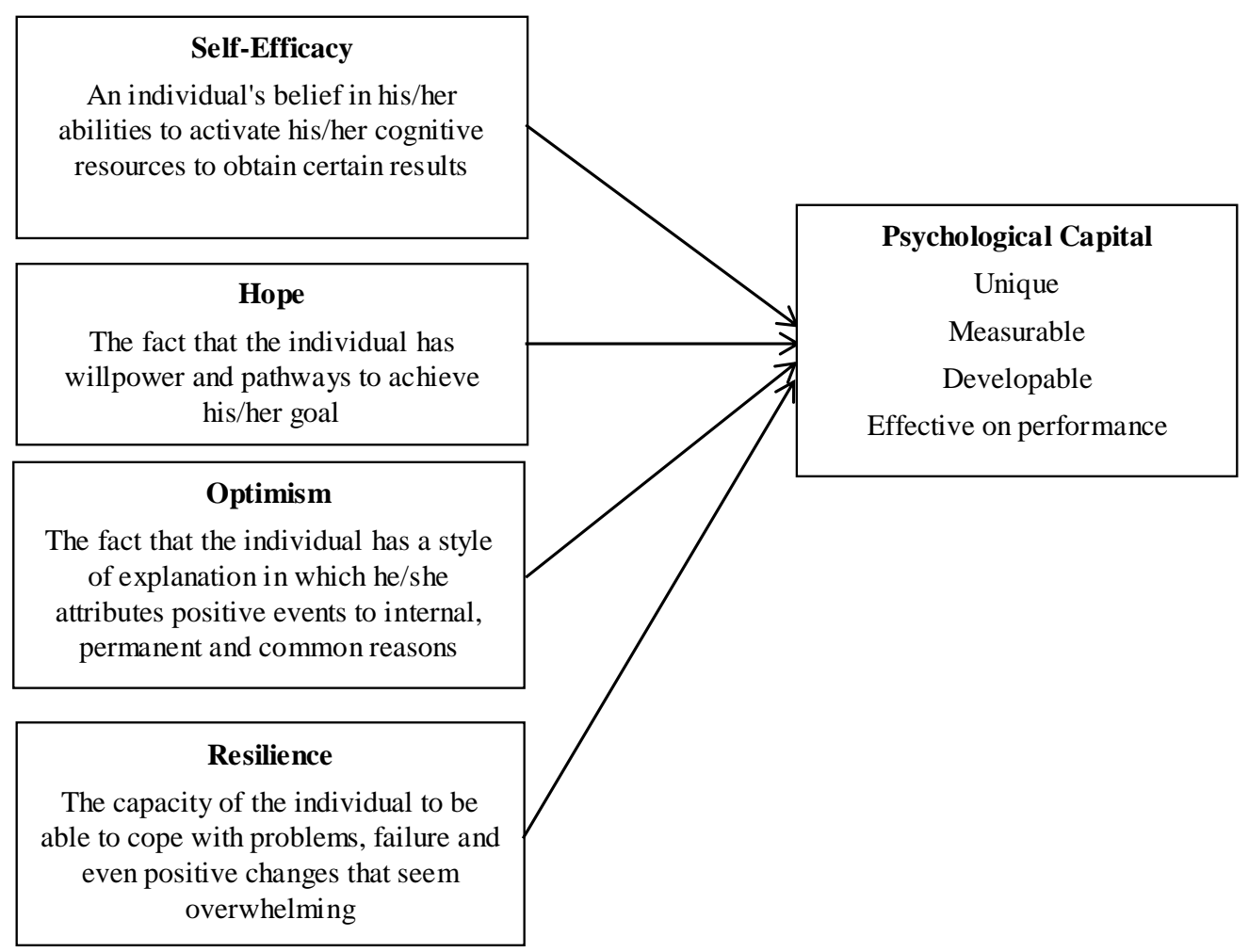

Figure 1. Components of psychological capital

Source: Fred Luthans and Carolyn M. Youssef, "Human, Social, and Now Positive Psychological Capital Management: Investing in People for Competitive Advantage", Organizational Dynamics, 2004, Vol. 33, No. 2, p. 152.

Although psychological capital consists of the components of self-efficacy, hope, optimism and resilience, it expresses more than the sum of its components, and it has a synergistic effect when components are brought together (Luthans et al., 2006: 388; Luthans, Youssef and Avolio, 2007: 19). As a high-level core structure, psychological capital combines the mechanisms (an internalized agency, motivation, perseverance, and success expectancies.) jointly owned by these four separate structures (Avey, Luthans and Youssef, 2010: 438; Avey et al., 2011: 130). Studies have shown that psychological capital predicts performance and job satisfaction better than the four 
individual components that comprise it (Luthans et al., 2007: 550; Avey, Luthans and Jensen, 2009: 683). On the other hand, although there is a clear conceptual similarity and overlap between self-efficacy, hope, optimism and resilience, each of these structures has been examined conceptually and empirically and proved to have construct validity (Luthans et al., 2008: 223; Avey, Luthans and Youssef, 2010: 437).

On the one hand, psychological capital, which emphasizes the positive nature and strengths of individuals and expresses the positive psychological resources that individuals possess, positively affects the development and performance of individuals, on the other hand, it also contributes to organizations to be able to recognize the importance of human factor better and to cope with the great challenges they may face now and in the future (Luthans, Luthans and Luthans, 2004: 49; Simons and Buitendach, 2013: 2).

Psychological capital that provides a developmental approach to increase positiveness in organizations (Youssef-Morgan, 2014: 138) is stated to be associated with desirable organizational outcomes and sustainable high performance in employees (Eid et al., 2012: 55). Furthermore, researchers state that to have knowledge about the psychological capital of organization employees can provide information about an organization's viability, psychological health and expected performance in the future and importantly emphasize that this knowledge can also be used in the selection of employees with a high potential to contribute to the organization and in ensuring their retention (Simons and Buitendach, 2013: 10).

In this context, organizations should include various applications for the development and effective management of psychological capital within the organization by focusing on this new form of capital which is vital for the long-term success and competitive advantage. They also should bring their approaches that provide a basis for these applications in compliance with the organization-specific, unique, their own situation and facts (Luthans and Youssef, 2004: 157).

\subsection{Personality}

Personality can be defined as the feeling, thought and behaviour pattern affecting the individual's expectations, values, attitudes and self-perception. In this context, personality includes steady characteristics that distinguish the individual from others, are specific to him/her, explain consistent behavioural patterns.

Although many and different things have been said about the definition of personality, it is observed that some common points are emphasized in the definitions made. These common points can be summarized as follows:

- Personality is a complex abstraction that involves the individual's genetic and learning backgrounds and reveals in what ways these factors affect the individual's reactions in various environments and situations. For this reason, many researchers accept personality studies as a scientific analysis of individual differences that help explain why and how individuals react to various environmental or situational demands (Ryckman, 2008: 4).

- Personality includes the individual's characteristics that are special and distinguish him/her from others. It is special because it represents individual-specific aspects. It is distinctive because these characteristics distinguish the person from the others (Morgan, 2011: 286). Ahmadi et al. (2012: 322) state that personality characteristics are rare, and sometimes, a person can be distinguished from other people by his/her unique characteristics.

- These characteristics, which distinguish the individual from the others, are a structured integrity. It is understood with this concept that personality is a system consisting of a large number of units and that each unit of the system has developed a pattern in relation to each other. There is no contradiction when a person is defined as "warm-hearted, helpful, calm, easy-going, devoted to his/her family". Personality characteristics have developed a consistent pattern, compatible with each other. On the other hand, it seems that there is an inconsistency when this person is defined as a "“warm-hearted, ill-tempered, easy-going, quarrelsome, highly respectful and aggressive person". Here, it is not possible to see the structure of the characteristics that make up the personality, and the way and the pattern they relate to each other (Cuceloglu, 2012: 405).

- Personality is the whole of characteristics explaining the consistent behavioural patterns of the individual. In this case, personality is stable and persistent against time and situations and refers to continuance within the individual from time to time or from state to state. Consistency does not mean that a person will inevitably behave in the same way at any time and in all cases. The individual has the ability to appropriately give reactions to the situation in which he/she is involved in line with his/her personality; however, his/her behaviours are not only composed of the reactions he/she gives to the situation in which 
he/she is involved. In other words, it is natural that we expect a consistency based on personality in an individual's behaviours (Yazgan Inanc and Yerlikaya, 2013: 3-4).

- The individual is in a constant relationship with his/her internal and external environments. In other words, the individual perceives the people, events, and objects that are outside of him/her as well as his/her own feelings and thoughts. The personality of the individual defines the form of relationship that he/she has established with his/her internal and external environments (Cuceloglu, 2012: 405).

In the literature, there are different models to explain personality characteristics. The Five-Factor Personality Model is a commonly used model in the explanation of personality characteristics, and this model was used in this study. The Five-Factor Personality Model is a model that organizes personality characteristics using five dimensions and that defines personality differences. This model is based on a distinctive trait approach. The distinctive trait approach is an approach aiming at analyzing the personality structure by measuring, identifying and classifying similarities and differences of personality characteristics or distinctive features. The basic unit for measuring personality characteristics is the distinctive feature. The distinctive feature is a relatively constant and permanent tendency to move in a certain way (Plotnik, 2009: 462).

The Five-Factor Personality Model provides a very short but comprehensive list of characteristics concerning all similarities or differences between the personalities and consists of relatively independent five dimensions including extraversion, conscientiousness, agreeableness, neuroticism and openness to experience.

Individuals who get high scores from the extraversion dimension are fun-loving, talkative, humorist, kindhearted, energetic, excited, enterprising, assertive, social, friendly, optimist, warm, active and self expressive people (Barrick and Mount, 1991: 3; Benet-Martinez and John, 1998: 730; Burger, 2006: 254; Yazgan Inanc and Yerlikaya, 2013: 288; Robbins and Judge, 2013: 138). Although individuals who get low scores from this dimension do not have the characteristics exhibited by individuals with high scores, this does not mean they are antisocial people without energy. Individuals who get low scores from this dimension are mostly shy, distant, tight-lipped, quiet, passive and anchorite people (Yazgan Inanc and Yerlikaya, 2013: 288). Similarly, Costa and McCrae (1992: 15) state that individuals whose extraversion characteristic is not high are not cold but shy people, not a viewer but independent people, not lazy but heavy-stepped people.

Individuals who get high scores from the conscientiousness dimension are careful, meticulous, responsible, determined, reliable, organized, planned, diligent, hardworking, success-oriented and persevering people (Barrick and Mount, 1991: 4; Burger, 2006: 255; Kumar and Bakhshi, 2010: 26; Robbins and Judge, 2013: 138). Individuals who get low scores from this dimension are easily distracted, aimless, disorganized, delinquent and unreliable people (Burger, 2006: 255; Yazgan Inanc and Yerlikaya, 2013: 288; Robbins and Judge, 2013: 138).

Agreeableness indicates the tendency of an individual to comply with other individuals (Robbins and Judge, 2013: 138). Individuals who get high scores from this dimension are polite, reliable, merciful, well-natured, tolerant, benevolent, easy-going, self-sacrificing, loving, thoughtful, friendly and collaborative people who get along with others and can easily adapt to changing conditions (Barrick and Mount, 1991: 4; Barrick, Mount and Judge, 2001: 11; Burger, 2006: 254; Wang and Erdheim, 2007: 1495; Kumar and Bakhshi, 2010: 26). Individuals who get low scores from the agreeableness dimension have a distant, disharmonious, opposing, suspicious, critical, short-tempered, stingy, indifferent to others, egocentric, hostile and jealous structure (Wang and Erdheim, 2007: 1495; Yazgan Inanc and Yerlikaya, 2013: 288; Robbins and Judge, 2013: 138).

Individuals who get high scores from the neuroticism dimension are affective, anxious, depressive, angry, nervous, unrestful, pessimistic, embarrassed, insecure, defensive and temperamental people (Barrick and Mount, 1991: 4; Wayne, Musisca and Fleeson, 2004: 112; Kappagoda 2013: 3). Individuals with the low level of neuroticism are calm, well-adapted people who are not inclined to excessive and incompatible emotional reactions (Burger, 2006: 254).

Individuals who get high scores from the openness to experience dimension are artistically sensitive, broad-minded, intelligent, scientifically and artistically creative, cultured, curious, original people with high imagination and untraditional and independent thoughts (Barrick and Mount, 1991: 5; Barrick, Mount and Judge, 2001: 11; Burger, 2006: 254; Kumar and Bakhshi, 2010: 26). Individuals who get low scores from this dimension are the people who are conservative and not too much curious, are inclined to protect traditional values and to maintain a particular lifestyle, prefer the things, people and experiences to which they are accustomed instead of new things, people or experiences (Yazgan Inanc and Yerlikaya, 2013: 288; Robbins and Judge, 2013: 138; Burger, 2006: 254). 
Researchers state that the Five-Factor Personality Model provides organizations with very important information about individual differences (Barrick and Mount, 1991: 5; Kumar and Bakhshi, 2010: 26). Luthans and Youssef (2007: 324) indicate that the five-factor personality dimensions are associated with the choice of profession, job performance, entrepreneurship, cultural intelligence, teamwork and burnout. Similarly, Somer (1998: 18-19) emphasizes the relationships between five-factor personality dimensions and job satisfaction, creativity, overcoming the stress, organizational commitment, motivation and quitting the work.

\subsection{Organizational Commitment}

When the literature on organizational commitment is considered, it is observed that there is very few consensus about the meaning of the concept. Along with the growth and development of the field, researchers from various disciplines have interpreted the subject in their own way, so the difficulty in understanding the structure has gradually increased (Mowday, Porter and Steers, 1982: 20).

Morrow and McElroy (1986: 139) state that many concepts related to organizational commitment have been developed since 1956 and that although self-sacrifice, faithfulness or commitment can be regarded as one-dimensional concepts, these concepts have been evaluated in a wider range in studies and used as protestant work ethic, career and caring the work, involvement in the work, the presence of the job at the centre of life, and organizational commitment.

Mowday, Steers and Porter (1979: 225), Mowday, Porter and Steers (1982: 20) indicate the definitions of organizational commitment made by various researchers as follows: The nature of the relationship of a member with the whole system; the process of bringing the purposes of the organization in conformity with the purposes of the individual or integration process; an orientation or attitude that connects individual's identity to the organization; a structural phenomenon resulting from individual-organizational processes and changes in side bets or investments over time.

Allen and Meyer (1990: 2) indicate that although there are various approaches to commitment in the literature, all of these approaches reflect one of three basic components consisting of affective attachment, perceived cost and obligation. They also formed their own approaches based on these three components. Nowadays, Allen and Meyer's approach is used by many researchers in studies on organizational commitment. In our study, Allen and Meyer's three-component model of commitment was taken as a basis, and the study was carried out in this context.

The commitment model developed by Allen and Meyer (1990: 3) has three components, and these components are called affective commitment, continuance commitment and normative commitment. The affective commitment refers to the identification, involvement and emotional attachment of the individual to the organization. The continuance commitment refers to the fact that the individual is aware of the costs of separation from the organization and decides to stay or leave the organization by taking into account these costs. The normative commitment reflects the feeling of obligation of an individual to stay in the organization (Meyer and Allen, 1991: 67; Allen and Meyer, 1996: 253).

The common aspect of affective commitment, continuance commitment and normative commitment is the formation of a link between the individual and the organization that reduces the likelihood of separation from the organization. However, the nature of this link varies depending on the relevant types of commitment (Allen and Meyer, 1990: 3). Employees with strong affective commitment to the organization stay in the organization because they want to stay in the organization, employees with strong continuance commitment to the organization stay in the organization because they need the organization, and employees with strong normative commitment to the organization stay in the organization because they feel they have to stay in the organization (Allen and Meyer, 1990: 3; Meyer and Allen, 1991: 67; Meyer, Allen and Smith, 1993: 539; Allen and Meyer, 1996: 253; Meyer and Allen, 1997: 11).

Meyer and Allen (1991: 67), Meyer, Allen and Smith (1993: 539), Meyer and Allen (1997: 11) indicate that all three commitments are a psychological state that reflects the relationship of the individual with the organization and is effective in deciding whether to continue or stop membership of the organization.

Affective commitment, continuance commitment, and normative commitment are considered to be the components of commitment that can be separated from each other, not as the types of commitment. In other words, employees may experience each of these psychological states at different levels. For example, some employees may feel a strong need and a sense of necessity to stay in the organization while they may not have the desire to stay in the organization. Some employees may feel a strong desire to stay in the organization while they may feel neither need nor necessity (Allen and Meyer, 1990: 3-4; Meyer and Allen, 1991: 67-68). For this reason, the sum of the employee's commitment to the organization reflects each of these psychological states that can be separated from each other (Allen and Meyer, 1990: 4). 
The studies carried out reveal organizational commitment's relationship with the results such as job satisfaction, organizational citizenship behaviour, job performance, employee turnover, intention to leave, absenteeism, etc.

\subsection{Relationships Between Organizational Commitment, Psychological Capital and Personality}

The relationships between the concepts that constitute the subject of the study have been studied by some researchers in the literature. However, while the relationship between psychological capital and personality is discussed in a small number of studies, it is remarkable that more studies have been carried out on the relationship of organizational commitment with these concepts.

In the literature, there is a limited number of studies revealing the relationships between psychological capital and personality. For example, Luthans et al. (2007: 541-572) stated in their study that there is a positive relationship between psychological capital and extraversion and conscientiousness. No relationship was found between psychological capital and agreeableness and openness to experience. Similarly, Avey, Luthans and Youssef (2010: 430-452) revealed in their study that there is a positive relationship between psychological capital and extraversion and conscientiousness.

In the study carried out by Brandt, Gomes and Boyanova (2011: 263-289) on a total of 231 people from three countries, Bulgaria, Finland and Portugal, they determined that there was a positive relationship between extraversion and psychological capital.

Cetin (2015: 149) revealed that there was a positive relationship between psychological capital and extraversion, conscientiousness and openness to experience and that there was a negative relationship between psychological capital and neuroticism.

In the literature, there are also studies that reveal the relationships between organizational commitment and psychological capital. For example, Luthans et al. (2007: 541-572) stated in their study that psychological capital positively affected the affective commitment. Lifeng (2007: 328-334) indicated that psychological capital positively affected the organizational commitment.

In three separate studies including the students from business administration, insurance business employees and the engineers and technicians working in the high technology sector, Luthans et al. (2008: 219-238) revealed that there was a positive relationship between psychological capital and organizational commitment. Similarly, Avey et al. (2011: 127-152) stated in their study that there was a positive relationship between psychological capital and organizational commitment.

The findings of the study carried out by Cetin (2011: 373-380) on 213 employees working in different units of Ministries and affiliated institutions in Ankara show that hope and optimism, which are the components of psychological capital, positively affect the organizational commitment. No relationship was found between self-efficacy and resilience and organizational commitment.

In the study including 132 employees working in a commercial enterprise in Iran, Etebarian, Tavakoli and Abzari (2012: 5057-5060) revealed that there was a positive relationship between psychological capital and affective commitment. No relationship was found between continuance commitment and normative commitment and psychological capital.

In their study including 106 people working in a call centre in South Africa, Simons and Buitendach (2013: 1-12) indicated that there was a positive relationship between psychological capital and organizational commitment. Similarly, Diržyte et al. (2013: 115-122) showed in their study that there was a positive relationship between psychological capital and organizational commitment.

The findings of the study carried out by Totawar and Nambudiri (2014: 83-97) on 440 service sector employees in India reveal that employees' psychological capitals positively affect their organizational commitment. Sharifi and Shahtalebi (2014: 23-30) stated in their study that there was a positive relationship between psychological capital's components and organizational commitment.

In the study carried out by Lather and Kaur (2015: 102-112) on 150 teachers working in private and public schools in India, they revealed that psychological capital positively affected the organizational commitment. Similarly, Sahoo and Sia (2015: 230-244), Ahmadi, Shahbazi and Hashemian (2015: 868-874) showed in their study that psychological capital positively affected the organizational commitment.

In the study carried out by Ocak, Guler and Basim (2016: 113-130) on 215 Bosnian teachers working in Bosnia, they stated that optimism, one of the components of psychological capital, positively affected the organizational 
commitment. No relationship was determined between self-efficacy, hope and resilience and organizational commitment.

Among the studies revealing the relationships between organizational commitment and personality, the findings of the study, which was carried out by Kumar and Bakhshi (2010: 25-34) on 187 doctors working in health college in India, show that there is a positive relationship between extraversion and affective commitment, continuance commitment and normative commitment, that there is a positive relationship between conscientiousness and affective commitment and continuance commitment, that there is a positive relationship between agreeableness and normative commitment, that there is a positive relationship between neuroticism and continuance commitment, and that there is a negative relationship between openness to experience and normative commitment and continuance commitment. In the study, no relationship was determined between conscientiousness and normative commitment.

Ahmadi et al. (2012: 321-326), in their study carried out on 183 people from the Persian Agriculture Organization, found that there was a positive relationship between extraversion and organizational commitment, that there was a positive relationship between conscientiousness and organizational commitment, that there was a positive relationship between agreeableness and organizational commitment, and that there was a negative relationship between neuroticism and organizational commitment.

In the study carried out by Tanriverdi (2012: 189-210) on 340 employees of a total of six private hospitals operating in Istanbul province, it was indicated that agreeableness and conscientiousness positively affected the organizational commitment. Similarly, Hackney (2012: 77) revealed that conscientiousness positively affected the organizational commitment.

The findings of the study carried out by Recepoglu et al. (2013: 603-617) on 154 instructors working in a state university show that there is a positive relationship between extraversion and affective commitment. No relationship was determined between extraversion and continuance commitment and normative commitment. In the study, a positive relationship was found between conscientiousness and affective commitment and normative commitment, and a negative relationship was found between conscientiousness and continuance commitment. In addition, a positive relationship was determined between agreeableness and affective commitment and normative commitment, a negative relationship was determined between agreeableness and continuance commitment. On the other hand, while a positive relationship was determined between neuroticism and continuance commitment, it was determined that neuroticism was not associated with affective commitment and normative commitment. No relationship was determined between openness to experience and affective commitment, continuance commitment and normative commitment.

In the study including 450 English teachers working in Sri Lanka public schools, Kappagoda (2013: 1-10) stated that extraversion, conscientiousness and agreeableness had a positive effect on organizational commitment and that neuroticism and openness to experience did not affect the organizational commitment.

In the study carried out by Kilic and Bozkaya (2014: 153-178) on 216 people working in a public institution, they indicated that extraversion positively affected the affective commitment and normative commitment and had no effect on continuance commitment. It was found out that conscientiousness positively affected the affective commitment and normative commitment but had no effect on continuance commitment. On the other hand, while it was found out that agreeableness positively affected the affective commitment, it had no effect on continuance commitment and normative commitment. While neuroticism positively affected the continuance commitment, it had no effect on affective commitment and normative commitment. It is also stated in the study that openness to experience positively affects the affective commitment and normative commitment but has no effect on continuance commitment.

In their study, Darbanyan et al. (2014: 12-17) indicate that there is a positive relationship between extraversion and normative commitment and that no relationship was determined between extraversion and affective commitment and continuance commitment. Furthermore, the findings of the study show that there is a positive relationship between conscientiousness and affective commitment and normative commitment. On the other hand, no relationship was found between conscientiousness and continuance commitment. There was a positive relationship between agreeableness and normative commitment, no relationship was determined between agreeableness and affective commitment and continuance commitment. There is a negative relationship between neuroticism and affective commitment and normative commitment while there is a positive relationship between neuroticism and continuance commitment. Finally, it is stated in the study that there is a positive relationship between openness to experience and affective commitment and that there is a negative relationship between openness to experience and continuance commitment. No relationship was determined between openness to experience and normative commitment. 
In the study carried out by Sadeghi and Yazdanbakhsh (2014: 28-36) on 216 teachers, they revealed a positive relationship between extraversion, conscientiousness, agreeableness and openness to experience and organizational commitment, and a negative relationship between neuroticism and organizational commitment.

In their study, Khoeini and Attar (2015: 61-64) showed that there was a positive relationship between agreeableness and continuance commitment, and there was a positive relationship between extraversion and affective commitment and normative commitment. On the other hand, no relationship was determined between neuroticism and openness to experience and affective commitment, continuance commitment and normative commitment.

\section{Research Methodology}

The study aims to examine the relationships between psychological capital and personality characteristics and organizational commitment. In this context, the sub-purposes of the study were determined to reveal

- The effect of psychological capital on organizational commitment,

- The effect of personality characteristics on organizational commitment,

- The relationships between psychological capital and personality characteristics.

In the light of the results of the study carried out, making a contribution to the literature related to the concepts and making guiding suggestions to practitioners are also among the purposes of the study.

The enterprise, which is the subject of the study, is a manufacturing enterprise which was founded in 1988 in Antakya, the centre of Hatay province, is operating at the national and international levels and produces furniture accessories. This enterprise continues its activities as a family-owned business. The products of the enterprise with the ISO 9001 certificate have a customer portfolio of various scales in the sector. This enterprise, which produces furniture accessories from plastic and metal materials, works in two and three shifts in some production lines. It has a total of 217 employees in manufacturing and administrative units.

The model of the study was defined to reveal the relationships between psychological capital, personality characteristics and organizational commitment within the frame of the Five-Factor Personality Model. The conceptual model of the study is presented in Figure 2.

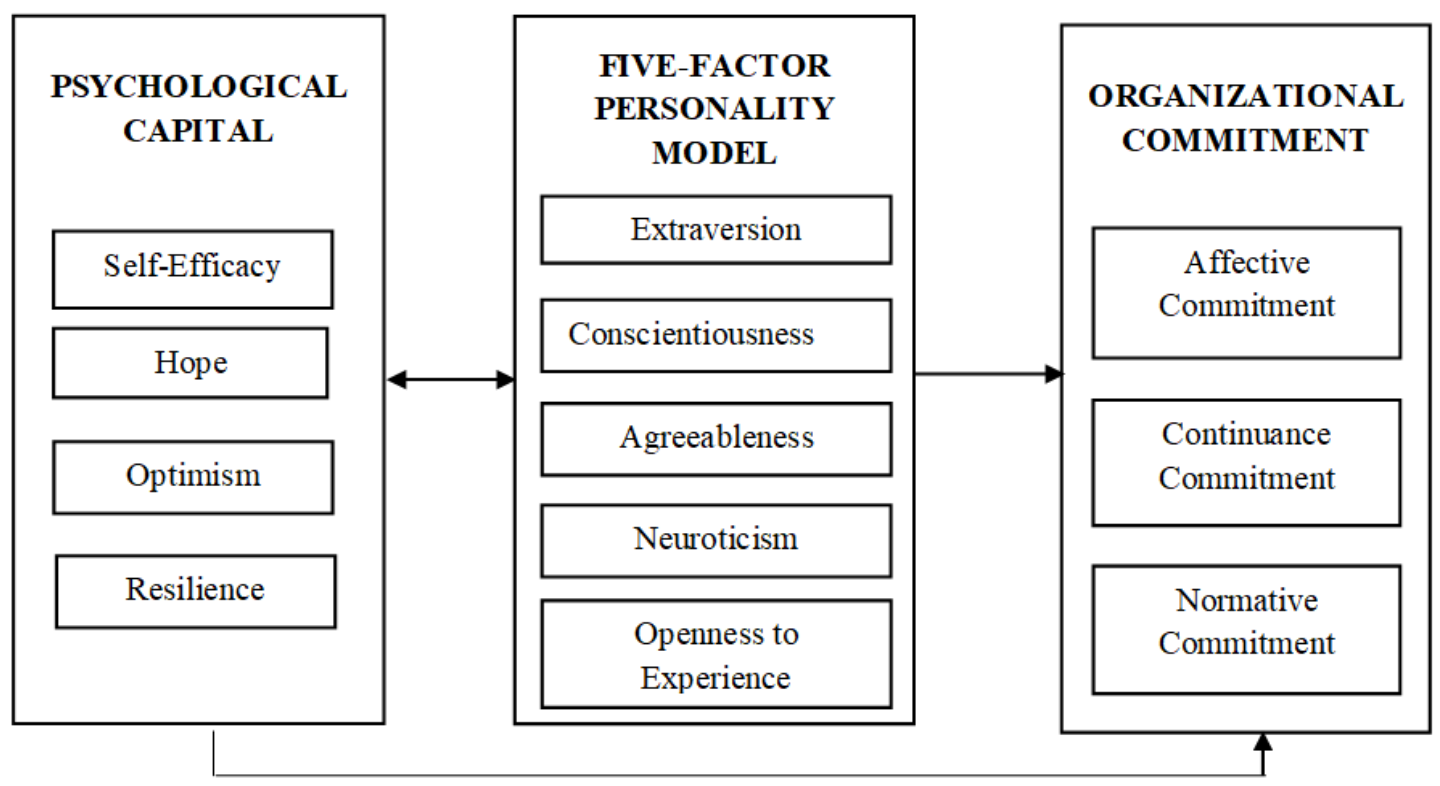

Figure 2. Conceptual model of the study

Psychological capital was measured using the scale which was developed by Luthans et al. (2007: 541-572) and translated into Turkish by Cetin and Basim (2012: 121-137). 
Personality was included in the research model as the Five Factor Personality Scale along with the scale which was developed by Benet-Martínez and John (1998: 729-750) and translated into Turkish by Nebi Sumer within the scope of the study carried out by Schmitt et al. (2007: 173-212).

The scale which was developed by Allen and Meyer (1990: 1-18), finalized by Meyer, Allen and Smith (1993: 538-551) and translated into Turkish by Wasti (2000: 401-410) was used for organizational commitment.

Research hypotheses were defined in accordance with the purpose of the study and determined as follows:

$\mathbf{H}_{\mathbf{1}}$ : Psychological capital positively affects organizational commitment.

$\mathbf{H}_{\mathbf{1 . 1}}$ : Psychological capital positively affects affective commitment.

$\mathbf{H}_{1.2}$ : Psychological capital positively affects continuance commitment.

$\mathbf{H}_{1.3}$ : Psychological capital positively affects normative commitment.

$\mathbf{H}_{2}$ : Extraversion positively affects organizational commitment.

$\mathbf{H}_{3}$ : Conscientiousness positively affects organizational commitment.

$\mathbf{H}_{4}$ : Agreeableness positively affects organizational commitment.

$\mathbf{H}_{5}$ : Neuroticism negatively affects organizational commitment.

$\mathbf{H}_{6}$ : Openness to experience positively affects organizational commitment.

$\mathbf{H}_{7}$ : There is a positive, significant relationship between psychological capital and extraversion.

$\mathbf{H}_{\mathbf{8}}$ : There is a positive, significant relationship between psychological capital and conscientiousness.

$\mathbf{H}_{\mathbf{9}}$ : There is a positive, significant relationship between psychological capital and agreeableness.

$\mathbf{H}_{\mathbf{1 0}}$ : There is a negative, significant relationship between psychological capital and neuroticism.

$\mathbf{H}_{11}$ : There is a positive, significant relationship between psychological capital and openness to experience.

The employees in manufacturing and administrative units of the above-mentioned furniture accessories manufacturer constituted the population of the study. During the data collection phase of the study, there were a total of 217 employees in the administrative and manufacturing units in the enterprise, and full count was performed.

The survey method was used as the data collection method in the study. The preliminary test was performed by testing the questionnaire form used for this purpose on 10 blue and white collar employees with different demographic characteristics. In particular, the ways of understanding and interpreting the questions of blue-collar employees were separately observed, and the questionnaire form was finalized by changing the differently perceived words without disrupting the meaning integrity. The collected data were analyzed with SPSS 21 and Lisrel 8.51, and the results were interpreted.

\section{Research Findings}

\subsection{Descriptive Information}

Descriptive information on the demographic characteristics of the employees and their working status in the enterprise are presented in Table 1. 
Table 1. Information on the demographic characteristics and working status of the employees

\begin{tabular}{|c|c|c|c|c|c|}
\hline & $\mathbf{n}$ & $\%$ & & $\mathbf{n}$ & $\%$ \\
\hline Age Groups & & & Working Time & & \\
\hline 20 years and below & 34 & 15,7 & 1 year and below & 86 & 39,6 \\
\hline $21-30$ & 74 & 34,1 & $2-4$ years & 68 & 31,3 \\
\hline $31-40$ & 76 & 35,0 & 5 years and above & 63 & 29,1 \\
\hline 41 and above & 33 & 15,2 & Total & 217 & 100,0 \\
\hline Total & 217 & 100,0 & & & \\
\hline Gender & & & Working area & & \\
\hline Female & 71 & 32,7 & Office & 21 & 9,7 \\
\hline Male & 146 & 67,3 & Manufacturing & 196 & 90,3 \\
\hline Total & 217 & 100,0 & Total & 217 & 100,0 \\
\hline Educational Status & & & Shift & & \\
\hline Primary education & 134 & 61,8 & First Shift & 167 & 85,2 \\
\hline High school & 67 & 30,9 & Second Shift & 16 & 8,2 \\
\hline Associate Degree & 9 & 4,1 & Third Shift & 13 & 6,6 \\
\hline Undergraduate and higher & 7 & 3,2 & Total & 196 & 100,0 \\
\hline Total & 217 & 100,0 & & & \\
\hline \multicolumn{6}{|l|}{ Marital status } \\
\hline Married & 123 & 56,7 & & & \\
\hline Single & 94 & 43,3 & & & \\
\hline Total & 217 & 100,0 & & & \\
\hline
\end{tabular}

Nearly $70 \%$ of employees are between the ages of $21-40$, and $67,3 \%$ of them are male. More than half of the employees are married and $61,8 \%$ of them are primary school graduates.

$29,1 \%$ of employees have worked in the enterprise for 5 years and above, $90,3 \%$ of them are employed in manufacturing units. As it is seen in Table 1, the ratio of those working in the second and third shifts is $14,8 \%$.

\subsection{Reliability Analysis}

The reliability analysis of the model variables was performed by Cronbach's Alpha. The results are presented in Table 2.

Table 2. Reliability analysis results of the model variables

\begin{tabular}{lcc}
\hline Model Variables & Number of Items & Cronbach's Alpha \\
\hline Self-Efficacy & 6 & 0,882 \\
Hope & 6 & 0,846 \\
Optimism & 6 & 0,584 \\
Resilience & 6 & 0,736 \\
Psychological Capital & 24 & 0,930 \\
(The Whole Scale) & 8 & 0,747 \\
\hline Extraversion & 9 & 0,747 \\
Conscientiousness & 9 & 0,695 \\
Agreeableness & 8 & 0,705 \\
Neuroticism & 10 & 0,711 \\
Openness to Experience & 44 & 0,806 \\
Five-Factor Personality & & 0,707 \\
(The Whole Scale) & 6 & 0,728 \\
\hline Affective Commitment & 6 & 0,716 \\
Continuance Commitment & 6 & 0,790 \\
Normative Commitment & 18 & \\
Organizational Commitment & & \\
(The Whole Scale) & &
\end{tabular}


The reliability of the psychological capital scale was generally found to be high, and the Cronbach's Alpha value of the optimistic component was obtained as 0,584 . It was observed that a similar value was obtained in some studies carried out on this subject.

When the Cronbach's Alpha values of the five-factor personality dimensions are examined, it can be said that the scale is reliable on the basis of each dimension and overall scale.

The Cronbach's alpha values of the organizational commitment and its components show that the reliability of the scale is high.

\subsection{Confirmatory Factor Analysis (CFA) Results}

The confirmatory factor analysis of the measurement models of each variable was performed to reveal the relationships between psychological capital, five-factor personality dimensions and organizational commitment variables by structural equation model. To obtain significant goodness of fit values during these analyses, a method of subtracting the factors with factor loadings below 0,40 and the factors with low factor loadings from the factors with meaning similarities was followed, as suggested by Saydan and Sututemiz (2009: 77-91). Because of the problems and low goodness of fit values during the analyses of some structures, the factors with an explained variance value $\left(R^{2}\right)$ below 0,30 were also excluded.

Table 3. Confirmatory factor analysis operations and the results

\begin{tabular}{|c|c|c|c|c|}
\hline Components & $\begin{array}{c}\text { Number } \\
\text { of Factors } \\
\text { Before } \\
\text { CFA }\end{array}$ & $\begin{array}{c}\text { Number } \\
\text { of } \\
\text { Factors } \\
\text { After } \\
\text { CFA }\end{array}$ & $\begin{array}{l}\text { Goodness of } \\
\text { Fit Values }\end{array}$ & Operations \\
\hline $\begin{array}{l}\text { Psychological } \\
\text { Capital }\end{array}$ & 24 & 18 & $\begin{array}{l}\text { RMSEA: } 0,078 \\
\chi^{2} / \mathrm{df}: 2,31 \\
\text { CFI: } 0,92 \\
\text { GFI: } 0,86 \\
\text { AGFI: } 0,82 \\
\text { NFI: } 0,86 \\
\text { IFI: } 0,92 \\
\end{array}$ & $\begin{array}{l}\text { The factors with factor loadings below } 0,40 \text {, with } \\
\text { meaning similarities and with an explained variance } \\
\text { value below } 0,30 \text { were examined at various stages } \\
\text { of the process, ultimately, } 3 \text { items of optimism } \\
\text { component, } 2 \text { items of resilience component and } 1 \\
\text { item of self-efficacy component were excluded } \\
\text { from the model. }\end{array}$ \\
\hline Extraversion & 8 & 6 & $\begin{array}{l}\text { RMSEA: } 0,000 \\
\chi^{2}: 3,71 \\
\text { df: } 7 \\
\text { CFI: } 1,00 \\
\text { GFI: } 0,99 \\
\text { AGFI: } 0,98 \\
\text { NFI: } 0,99 \\
\text { IFI: } 1,01\end{array}$ & $\begin{array}{l}2 \text { items were excluded since their factor loadings } \\
\text { were below } 0,40 \text {. }\end{array}$ \\
\hline Conscientiousness & 9 & 6 & $\begin{array}{l}\text { RMSEA: } 0,000 \\
\chi^{2}: 3,71 \\
\text { df: } 7 \\
\text { CFI: } 1,00 \\
\text { GFI: } 0,99 \\
\text { AGFI: } 0,98 \\
\text { NFI: } 0,99 \\
\text { IFI: } 1,01\end{array}$ & $\begin{array}{l}3 \text { items were excluded since their factor loadings } \\
\text { were below } 0,40 .\end{array}$ \\
\hline
\end{tabular}




\begin{tabular}{|c|c|c|c|c|}
\hline Agreeableness & 9 & 6 & $\begin{array}{l}\text { RMSEA: } 0,000 \\
\chi^{2}: 3,71 \\
\text { df: } 7 \\
\text { CFI: } 1,00 \\
\text { GFI: } 0,99 \\
\text { AGFI: } 0,98 \\
\text { NFI: } 0,99 \\
\text { IFI: } 1,01\end{array}$ & $\begin{array}{l}3 \text { items were excluded since their factor loadings } \\
\text { were below } 0,40 \text {. }\end{array}$ \\
\hline Neuroticism & 8 & 6 & $\begin{array}{l}\text { RMSEA: } 0,000 \\
\chi^{2}: 3,71 \\
\text { df: } 7 \\
\text { CFI: } 1,00 \\
\text { GFI: } 0,99 \\
\text { AGFI: } 0,98 \\
\text { NFI: } 0,99 \\
\text { IFI: } 1,01 \\
\end{array}$ & $\begin{array}{l}2 \text { items were excluded since their factor loadings } \\
\text { were below } 0,40 \text {. }\end{array}$ \\
\hline $\begin{array}{l}\text { Openness to } \\
\text { Experience }\end{array}$ & 10 & 7 & $\begin{array}{l}\text { RMSEA: } 0,000 \\
\chi^{2}: 10,20 \\
\text { df: } 12 \\
\text { CFI: } 1,00 \\
\text { GFI: } 0,99 \\
\text { AGFI: } 0,97 \\
\text { NFI: } 0,97 \\
\text { IFI: } 1,01\end{array}$ & $\begin{array}{l}3 \text { items were excluded since their factor loadings } \\
\text { were below } 0,40 \text {. }\end{array}$ \\
\hline $\begin{array}{l}\text { Organizational } \\
\text { Commitment }\end{array}$ & 18 & 11 & $\begin{array}{l}\text { RMSEA: } 0,078 \\
\chi^{2} / \mathrm{df}: 2,30 \\
\text { CFI: } 0,96 \\
\text { GFI: } 0,93 \\
\text { AGFI: } 0,88 \\
\text { NFI: } 0,93 \\
\text { IFI: } 0,96\end{array}$ & $\begin{array}{l}\text { Organizational commitment was analyzed with } \\
3 \text {-component } 18 \text { items; however, the covariance } \\
\text { matrix was not found positive in the first stage. So, } \\
\text { the factors with factor loadings below } 0,40 \text {, with } \\
\text { meaning similarities and with an explained variance } \\
\text { value below } 0,30 \text { were examined at various stages } \\
\text { of the process, ultimately, the positivity of the } \\
\text { covariance matrix was ensured by excluding } 3 \\
\text { items of affective commitment, } 3 \text { items of } \\
\text { continuance commitment and } 1 \text { item of normative } \\
\text { commitment from the model. }\end{array}$ \\
\hline
\end{tabular}

The results of the confirmatory factor analysis are presented in Table 3. Psychological capital was evaluated as a single factoral model consisting of 24 items with all its components to solve the problem that the covariance matrix was not defined positively, and it is observed that there also studies carried out based on this approach in the literature. At the end of the analysis, 24 items were decreased to 18 items.

Among the other variables in the model, 2 items of extraversion, 3 items of conscientiousness, 3 items of agreeableness, 2 items of neuroticism and 3 items of openness to experience were excluded. 7 items of the organizational commitment variable were excluded.

\subsection{Structural Equation Model Analyses of the Variables of the Model}

After the confirmatory factor analysis of the measurement models related to the study subject variables was performed, structural equation model studies were started. The analyses of the relevant models tested are presented below. 


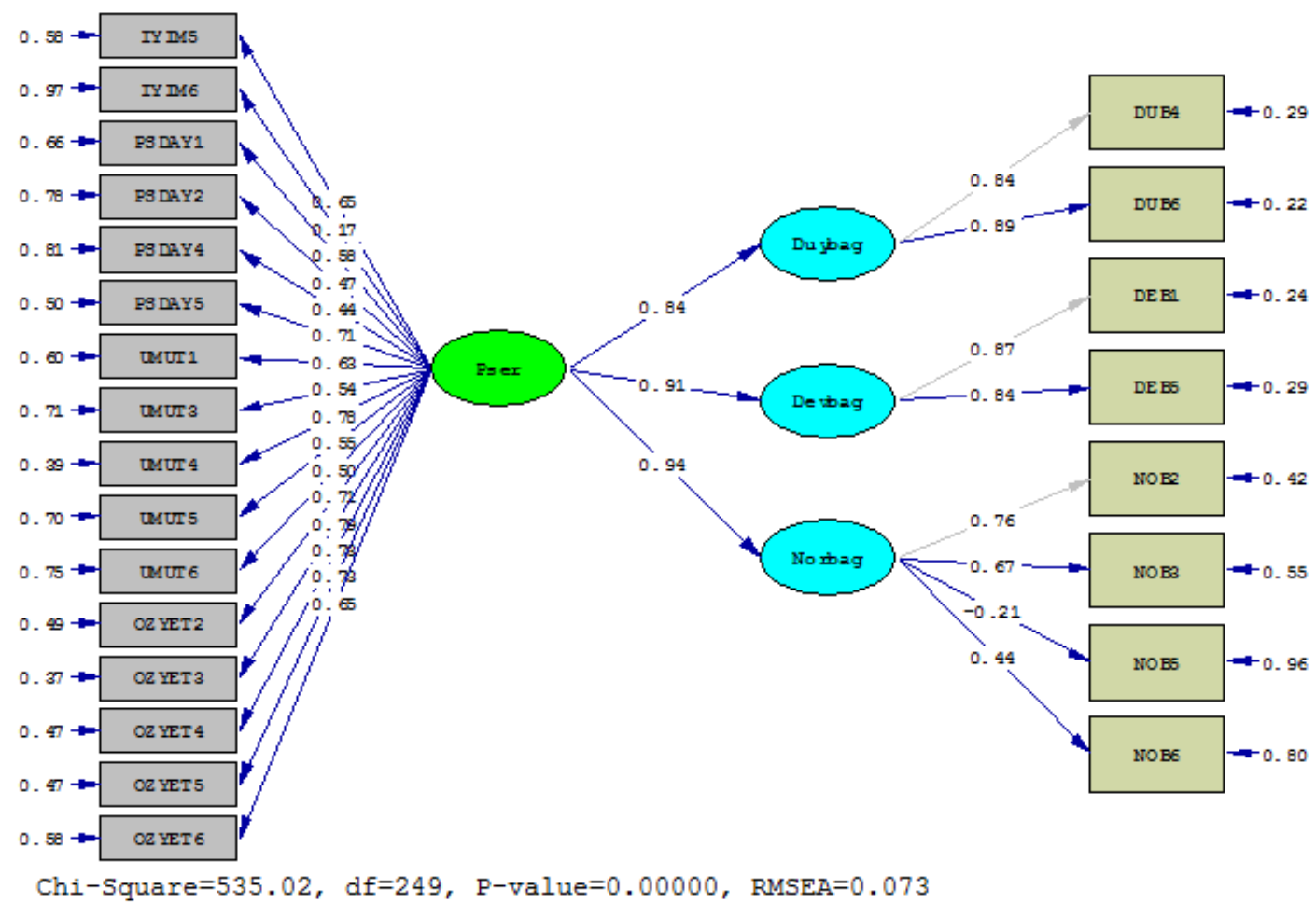

Figure 3. Standardized solution values regarding the effect of psychological capital on the organizational commitment components

The structural equation model results regarding the effect of psychological capital on the organizational commitment components are presented in Figure 3. During the analysis process, 1 item of optimism component, 1 item of hope component, 1 item of affective commitment component, 1 item of continuance commitment component and 1 item of normative commitment were excluded from the model because they were not statistically significant. As it is seen in Table 5, the goodness of fit values of the relevant model were found to be within the acceptable limits. When the standardized path coefficients of the final form of the model in Figure 3 are examined, it is observed that psychological capital positively affects all three components of organizational commitment. Psychological capital explains 0,70 of affective commitment, 0,83 of continuance commitment and 0,89 of normative commitment. The $\mathrm{t}$-values giving the significance test results of all standardized values in the model were also found to be significant. According to these results, hypothesis $\mathrm{H}_{1}$ and its sub-hypotheses were accepted.

Due to the very high correlation between the latent variables emerging in the confirmatory factor analysis for the measurement model of organizational commitment, it was resorted to reducing the items related to latent variables used in the structural equation modeling analyses to a single variable. By considering the aim of testing the model to preserve the relevant components with latent variable nature, the items of each component were put into operation among themselves, and the averages of the items were calculated. Therefore, DUYBAG (DUB2+DUB4+DUB6/3), DEVBAG (DEB1+DEB5+DEB6/3), NORBAG (NOB2+ NOB3+NOB4+NOB5+NOB6/5) were created, and these variables were transformed into an observed variable of the organizational commitment latent variable.

The models showing the effect of each personality dimension on organizational commitment are presented below. 


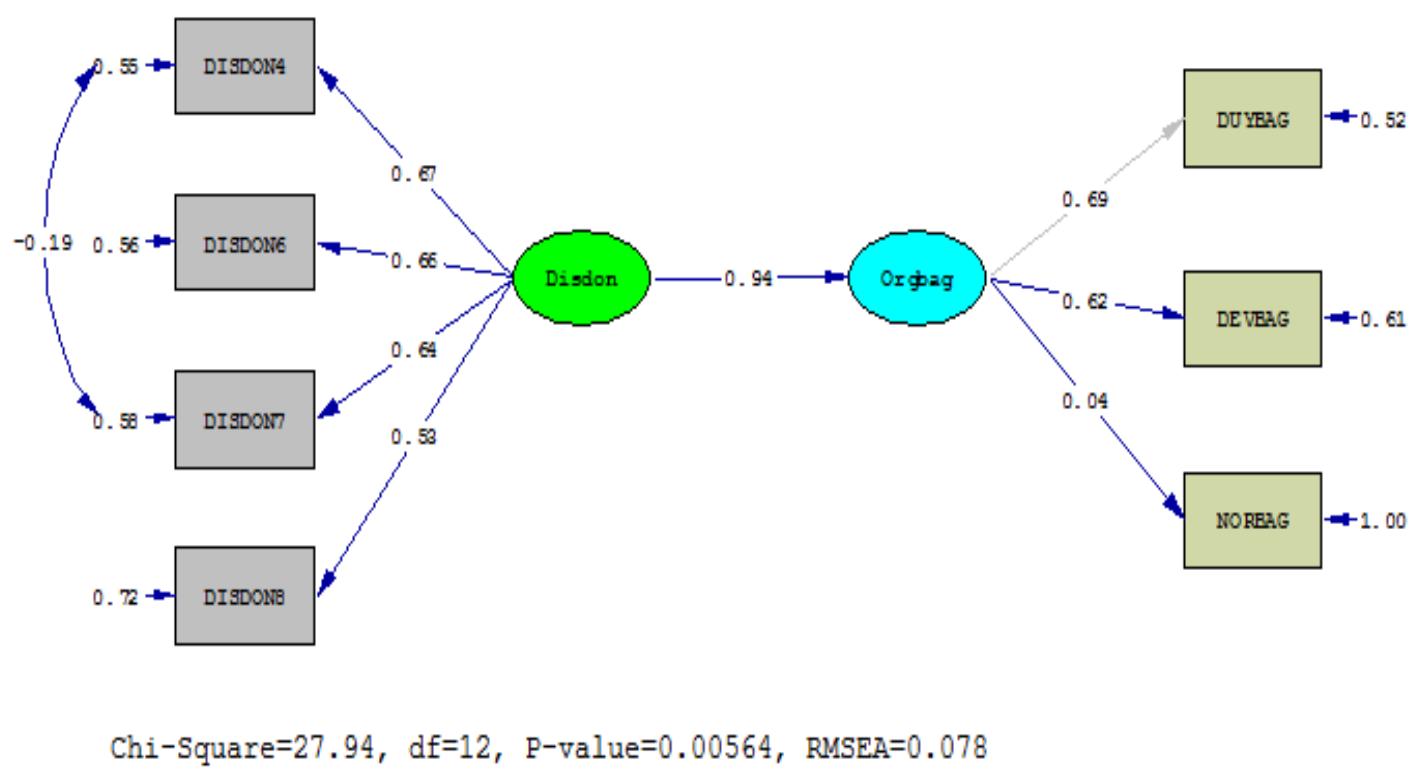

Figure 4. Standardized solution values regarding the effect of extraversion on organizational commitment

The structural equation model results regarding the effect of extraversion on organizational commitment are presented in Figure 4. During the analysis process, 2 items of the extraversion variable were excluded from the model because they were not statistically significant. As it is seen in Table 5, the goodness of fit values of the relevant model were found to be within the acceptable limits. When the standardized path coefficients of the final form of the model in Figure 4 are examined, it is observed that extraversion positively affects organizational commitment. Extraversion explains 0, 89 of organizational commitment. According to these results, hypothesis $\mathrm{H}_{2}$ was accepted.

Although the value of normative commitment was not found to be significant in the significance test of the factor loads, normative commitment was not excluded from the model to preserve the three-component structure of organizational commitment. 


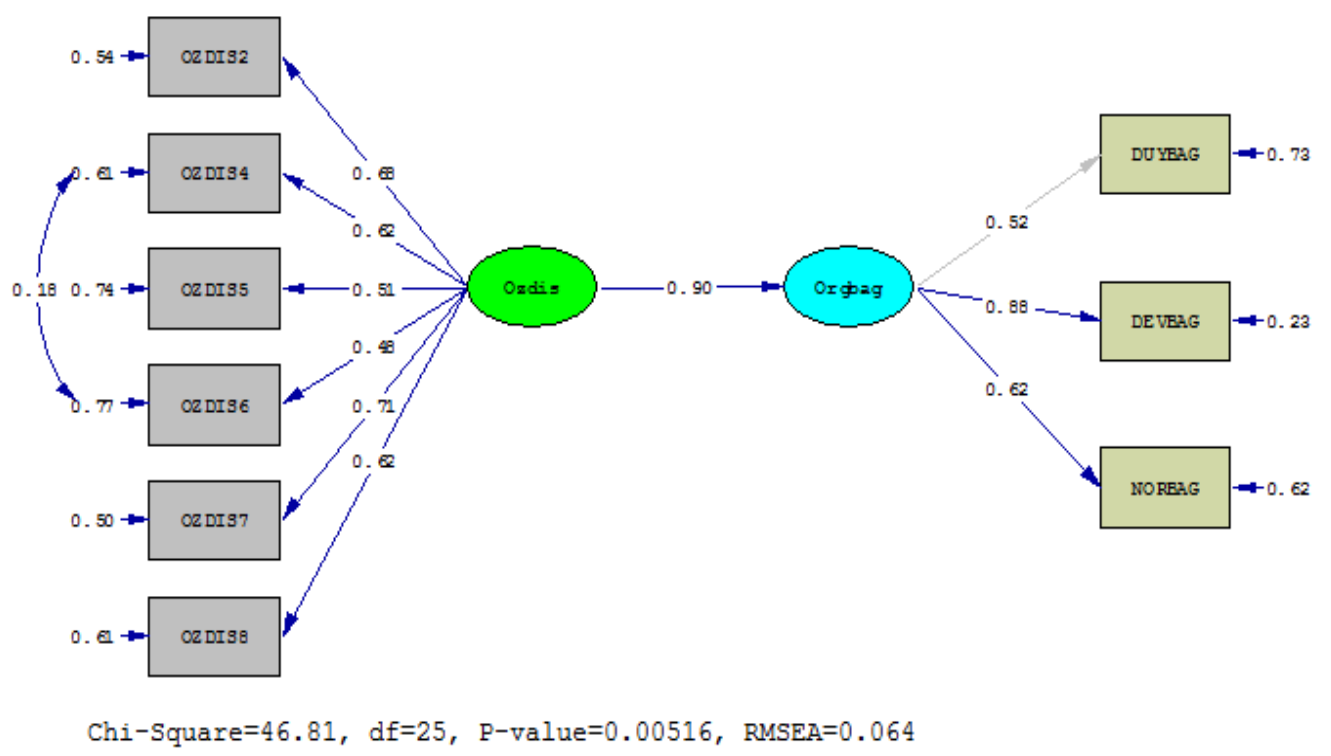

Figure 5. Standardized solution values regarding the effect of conscientiousness on organizational commitment

The structural equation model results regarding the effect of conscientiousness on organizational commitment are presented in Figure 5. As it is seen in Table 5, the goodness of fit values of the relevant model were found to be within the acceptable limits. When the standardized path coefficients in Figure 5 are examined, it is observed that conscientiousness positively affects organizational commitment. Conscientiousness explains 0,81 of organizational commitment. The $\mathrm{t}$-values giving the significance test results of all standardized values in the model were also found to be significant. According to these results, hypothesis $\mathrm{H}_{3}$ was accepted.

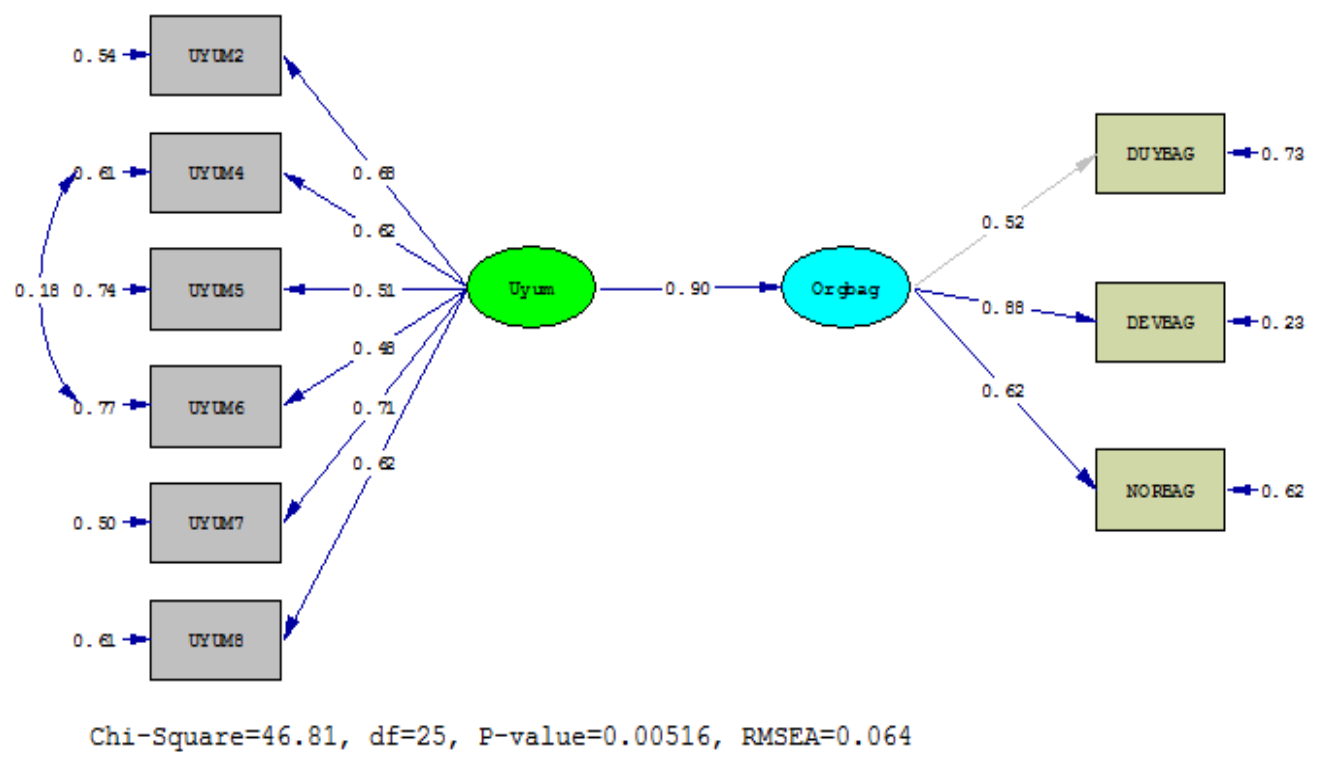

Figure 6. Standardized solution values regarding the effect of agreeableness on organizational commitment 
The structural equation model results regarding the effect of agreeableness on organizational commitment are presented in Figure 6. As it is seen in Table 5, the goodness of fit values of the relevant model were found to be within the acceptable limits. When the standardized path coefficients in Figure 6 are examined, it is observed that agreeableness positively affects organizational commitment. Agreeableness explains 0,81 of organizational commitment. The $\mathrm{t}$-values giving the significance test results of all standardized values in the model were also found to be significant. According to these results, hypothesis $\mathrm{H}_{4}$ was accepted.

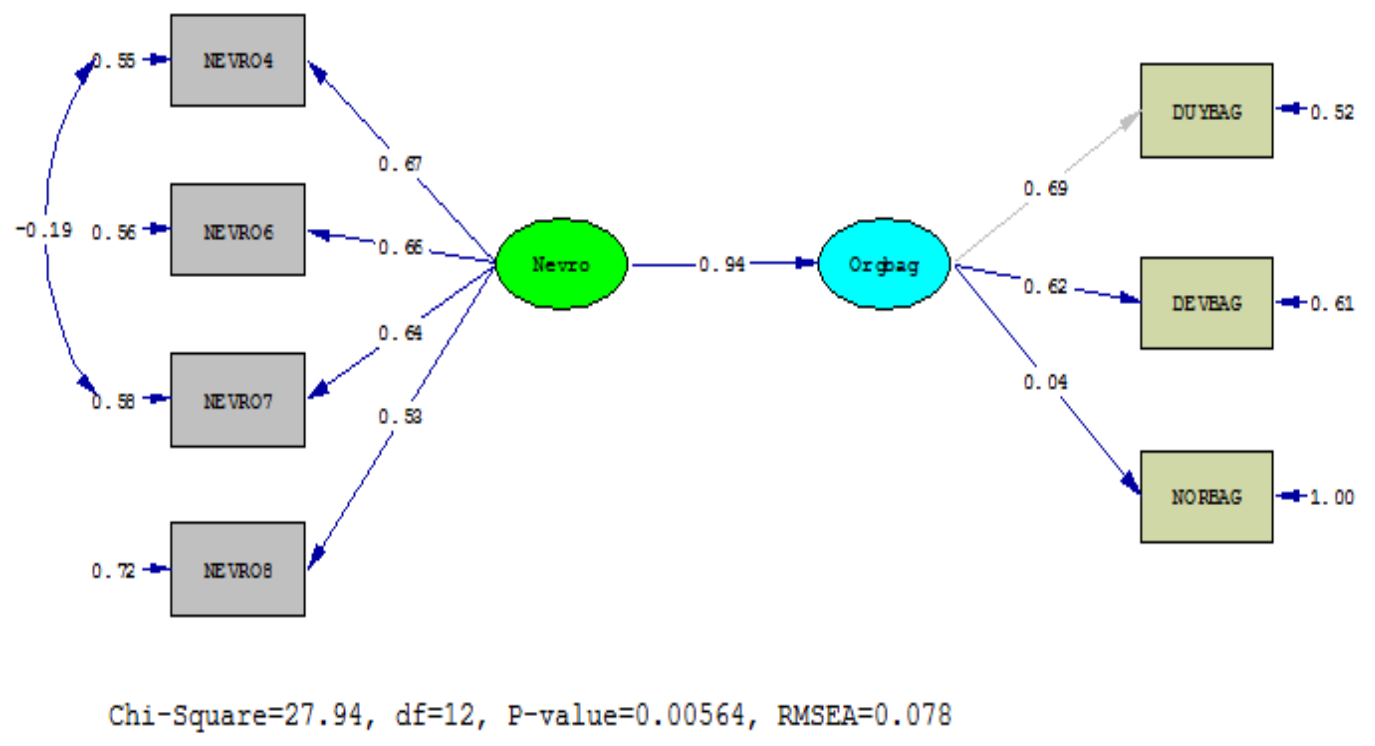

Figure 7. Standardized solution values regarding the effect of neuroticism on organizational commitment

The structural equation model results regarding the effect of neuroticism on organizational commitment are presented in Figure 7. During the analysis process, 2 items of the neuroticism variable were excluded from the model because they were not statistically significant. As it is seen in Table 5, the goodness of fit values of the relevant model were found to be within the acceptable limits. When the standardized path coefficients of the final form of the model in Figure 7 are examined, it is observed that neuroticism positively affects organizational commitment. Neuroticism explains 0, 89 of organizational commitment. According to these results, hypothesis $\mathrm{H}_{5}$ was rejected.

Although the value of normative commitment was not found to be significant in the significance test of the factor loads, normative commitment was not excluded from the model to preserve the three-component structure of organizational commitment. 


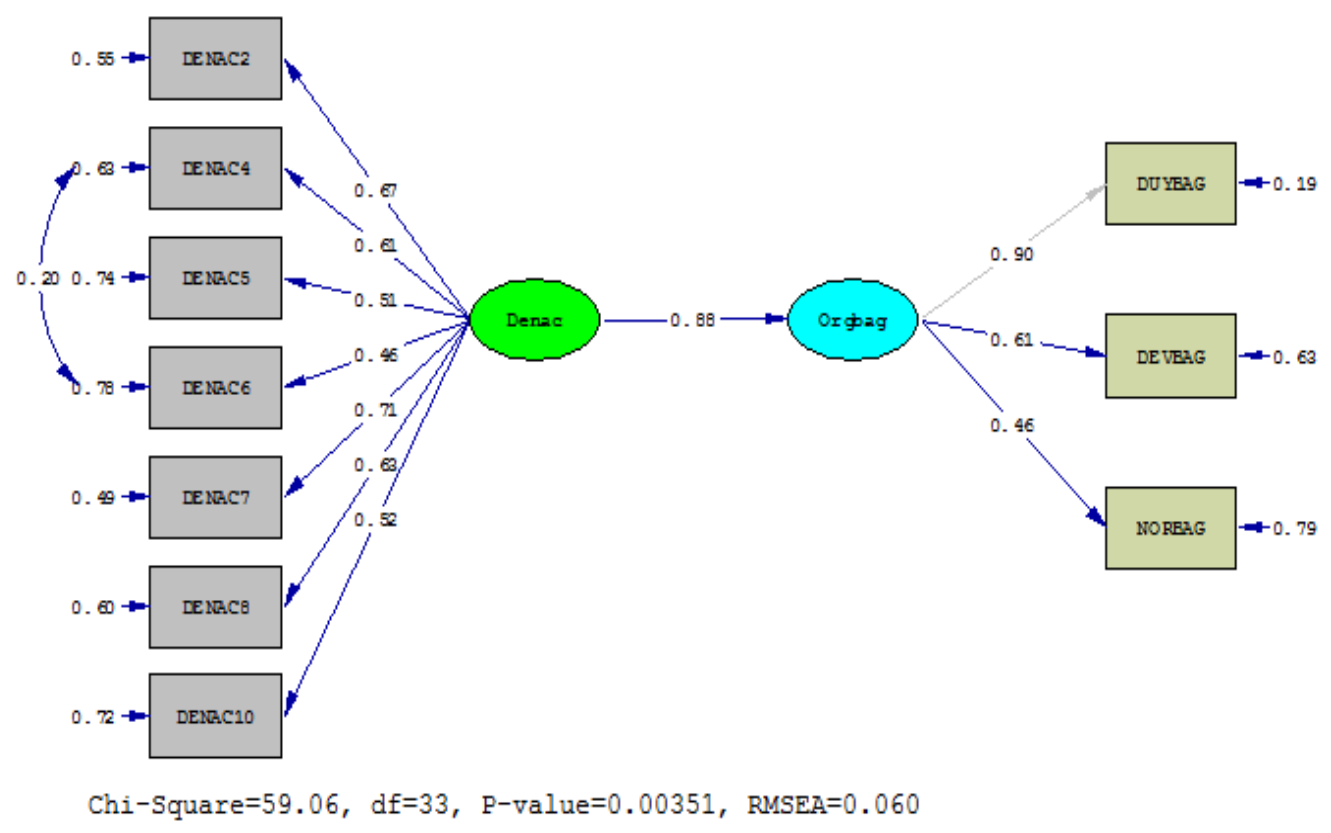

Figure 8. Standardized solution values regarding the effect of openness to experience on organizational commitment

The structural equation model results regarding the effect of openness to experience on organizational commitment are presented in Figure 8. As it is seen in Table 5, the goodness of fit values of the relevant model were found to be within the acceptable limits. When the standardized path coefficients in Figure 8 are examined, it is observed that openness to experience positively affects organizational commitment. Openness to experience explains 0,78 of organizational commitment. The t-values giving the significance test results of all standardized values in the model were also found to be significant. According to these results, hypothesis $\mathrm{H}_{6}$ was accepted. 


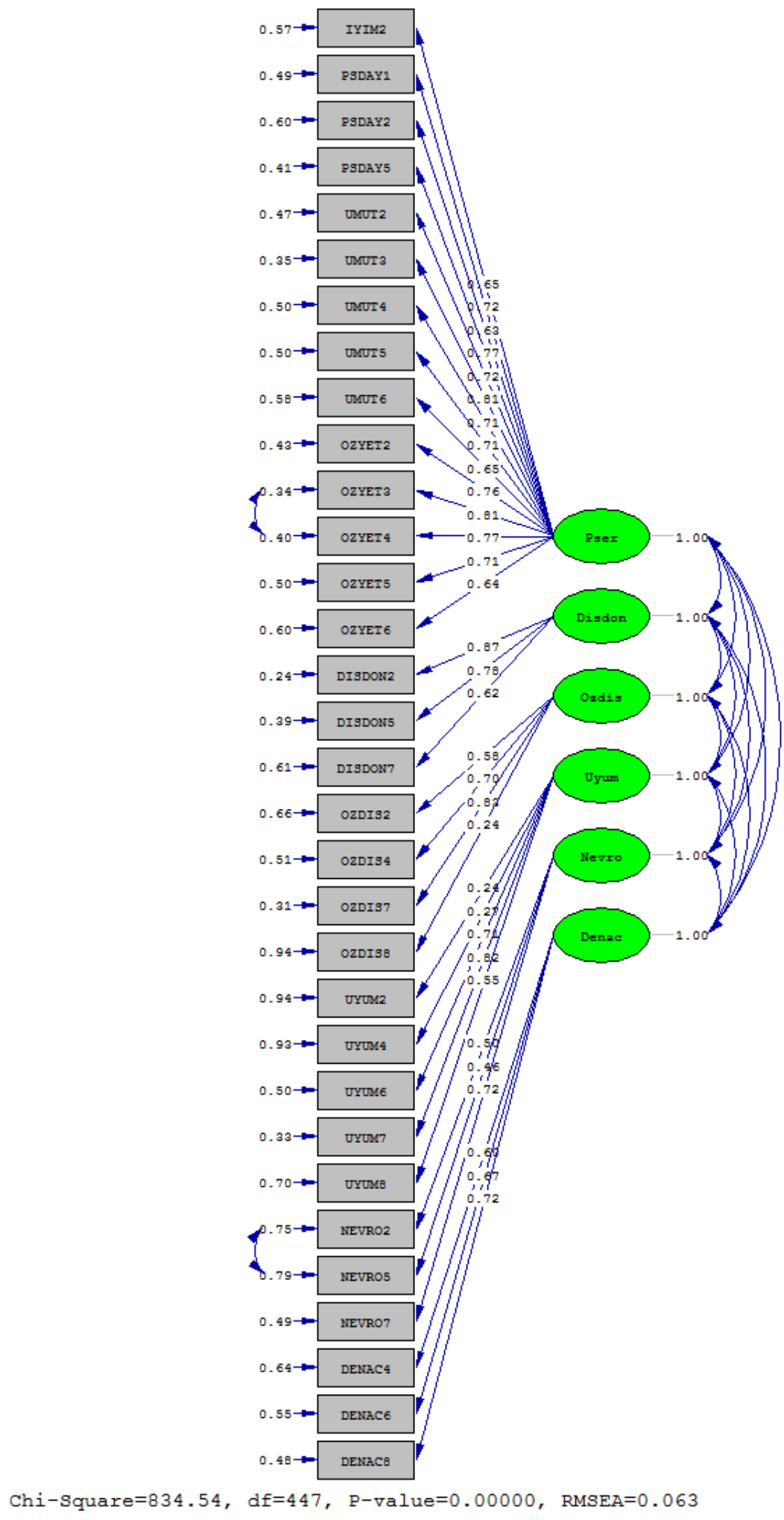

Figure 9. Standardized solution values regarding the relationship between psychological capital and five-factor personality dimensions 
Table 4. Correlation matrix showing the relationship between psychological capital and five-factor personality dimensions

\begin{tabular}{lcc}
\hline & & Psychological Capital \\
\hline \multirow{3}{*}{ Psychological Capital } & $\mathrm{r}$ & 1,00 \\
& St. error & \\
Extraversion & $\mathrm{t}$ & $-0,21$ \\
& $\mathrm{r}$ & 0,07 \\
& St.error & $-2,87$ \\
Conscientiousness & $\mathrm{t}$ & 0,67 \\
& $\mathrm{r}$ & 0,05 \\
Agreeableness & St.error & 13,55 \\
& $\mathrm{t}$ & 0,71 \\
& $\mathrm{r}$ & 0,05 \\
Neuroticism & St.error & 15,42 \\
& $\mathrm{t}$ & $-0,54$ \\
& $\mathrm{r}$ & 0,08 \\
Openness to Experience & St.error & $-6,99$ \\
& $\mathrm{t}$ & 0,52 \\
& $\mathrm{r}$ & 0,07 \\
& St.error & 7,87 \\
\hline
\end{tabular}

The measurement model results regarding the relationship between psychological capital and five-factor personality dimensions are presented in Figure 9. During the analysis process, 4 items of psychological capital variable, 3 items of extraversion variable, 2 items of conscientiousness variable, 1 item of agreeableness variable, 3 items of neuroticism variable and 4 items of openness to experience variable were excluded from the model because they were not statistically significant, or the variances they explained were below 0,30 . As it is seen in Table 5, the goodness of fit values of the relevant model were found to be within the acceptable limits.

When the standardized path coefficients of the final form of the model in Figure 9 and the correlation matrix in Table 4 were examined, the following results were obtained:

- There is a negative, weak relationship between psychological capital and extraversion;

- There is a positive, strong relationship between psychological capital and conscientiousness;

- There is a positive, strong relationship between psychological capital and agreeableness;

- There is a negative, moderately strong relationship between psychological capital and neuroticism;

- There is a positive, moderately strong relationship between psychological capital and openness to experience.

According to the results presented above, hypothesis $\mathrm{H}_{7}$ was rejected; hypotheses $\mathrm{H}_{8}, \mathrm{H}_{9}, \mathrm{H}_{10}, \mathrm{H}_{11}$ were accepted.

Table 5. Goodness of fit values of the models

\begin{tabular}{|c|c|c|c|c|c|c|c|}
\hline \multirow{2}{*}{ Models } & \multicolumn{7}{|c|}{ Goodness of Fit Criteria } \\
\hline & RMSEA & $\chi^{2} / \mathbf{d f}$ & CFI & GFI & AGFI & NFI & IFI \\
\hline $\begin{array}{l}\text { Effect of Psychological Capital on the Components } \\
\text { of Organizational Commitment }\end{array}$ & 0,073 & 2,15 & 0,89 & 0,83 & 0,79 & 0,81 & 0,89 \\
\hline $\begin{array}{l}\text { Effect of Extraversion on Organizational } \\
\text { Commitment }\end{array}$ & 0,078 & 2,33 & 0,95 & 0,96 & 0,92 & 0,92 & 0,96 \\
\hline $\begin{array}{l}\text { Effect of Conscientiousness on Organizational } \\
\text { Commitment }\end{array}$ & 0,064 & 1,87 & 0,96 & 0,95 & 0,92 & 0,92 & 0,96 \\
\hline $\begin{array}{l}\text { Effect of Agreeableness on Organizational } \\
\text { Commitment }\end{array}$ & 0,064 & 1,87 & 0,96 & 0,95 & 0,92 & 0,92 & 0,96 \\
\hline $\begin{array}{l}\text { Effect of Neuroticism on Organizational } \\
\text { Commitment }\end{array}$ & 0,078 & 2,33 & 0,95 & 0,96 & 0,92 & 0,92 & 0,96 \\
\hline $\begin{array}{l}\text { Effect of Openness to Experience on Organizational } \\
\text { Commitment }\end{array}$ & 0,060 & 1,79 & 0,96 & 0,95 & 0,91 & 0,91 & 0,96 \\
\hline $\begin{array}{l}\text { Relationship between Psychological Capital and } \\
\text { Five-Factor Personality Dimensions }\end{array}$ & 0,063 & 1,86 & 0,87 & 0,81 & 0,77 & 0,77 & 0,88 \\
\hline
\end{tabular}




\section{Conclusion}

Psychological capital, which is one of the new concepts of organizational behaviour field, is a concept on which great numbers of studies have not been carried out yet. Its relationship with organizational commitment is considered to be a current issue which is still being studied. The fact that the subjects of positive psychology, positive organizational behaviour and psychological capital have been a reference to scientific studies after many years of studies of psychology towards negative has ensured that these concepts have quickly attracted attention. These concepts developed within the theoretical framework have been supported by the findings of empirical studies and have provided significant area of discussion and contribution to researchers.

Psychological capital and its components that focus on the positive aspects of employees and are directed towards the development of these aspects play a significant role in the effect on the performance of employees and organizations. Studies show that another of these areas of influence is the organizational commitment of employees.

In addition to the psychological capital of employees, their personality characteristics also have a significant influence on organizational commitment. It is observed that the studies carried out on this subject confirm the relevant influence. The Five-Factor Personality Model, which is commonly used and universally accepted in the literature, was the model used in study. In this context, the fact that personality characteristics have a significant effect on the organizational commitment of employees has been revealed by various studies.

The relationship of personality characteristics with psychological capital has also been discussed in the studies in the literature. It is stated by many researchers that personality characteristics are relatively more stable, whereas psychological capital is state-like and developable. However, the relationships between these two concepts have been revealed by a small number of studies. It is observed that there is no clear and common view on which of these concepts affects the other.

In this context, the relationship between psychological capital and personality characteristics was investigated in the study, and the results parallel to the findings in the literature were obtained. According to the research results, a positive and significant relationship was found between psychological capital and conscientiousness, agreeableness and openness to experience of personality characteristics. Accordingly, there is a positive relationship between employees' psychological capitals and being careful, meticulous, responsible, reliable, helpful, curious, highly imaginative and creative.

A negative and significant relationship was found between psychological capital and neurotic personality, in accordance with findings in the literature. Employees with a high neuroticism level, for example, anxious, depressive, angry, nervous and unrestful people have a low level of psychological capital.

In the research findings, contrary to expectations, a negative and significant relationship was achieved between psychological capital and extraversion. When the employees' psychological capital level averages and extraversion averages were compared out of 5 , it was determined that the average of the psychological capital level $(4,5305)$ was higher than the average of extraversion $(3,3980)$. Therefore, it can be said that the result obtained was caused by this situation.

In the study, it is observed that psychological capital has a positive effect on all three sub-components of organizational commitment. Therefore, it can be said that psychological capital is an important determinant of employees' affective, continuance and normative commitments. The improvement in employees' positive psychological state directly affects their commitment to the organization. The more positive the improvement is, all three types of commitment increase in the same way. In this context, it is also revealed how important the fact that business managers take into account the psychological capitals of their employees is. The employee whose level of commitment to the organization increases in this way work more efficiently and effectively.

Another factor affecting organizational commitment is the personality characteristics of employees. It is observed that the whole personality characteristics discussed within the frame of the Five-Factor Personality Model positively and significantly affect organizational commitment. Among the results, contrary to expectations, the fact that neuroticism positively affects employees' organizational commitment levels attracts attention. It can be thought that one of the probable reasons for this result is the fact that the employee does not want to leave the enterprise with anxiety about not being able to find another job by being aware of this characteristic. The feeling and thought of these employees, who are generally insecure about their environment, to keep themselves safe against the uncertainty of the outside world in the existing enterprise they regard as a more safeguarded structure can also be the another reason. 
Research findings show that strengthening the psychological capital of employees is an important area of study in terms of business management. The organizational commitment levels of employees also increase directly and/or through their work experiences as these characteristics are improved. Therefore, training of employees, enabling or supporting their personal development, establishing suggestion systems, providing feedback on the performance identified in a realistic way and the fact that they are supported by the management are highly important.

Similarly, it was also concluded that personality characteristics affected organizational commitment. For employees with different personality characteristics to achieve the common purposes and objectives of the enterprise, management should realize the importance of these differences, and managers should communicate more closely with their employees, should follow the behaviours of the people they work with and should direct them in the light of the information they have obtained. For this purpose, however, senior managements should also plan and implement the training that will enable managers to improve their knowledge and skills in these issues. Furthermore, the fact that managers manage the process by having knowledge about the personality characteristics of the employee before employment using the tools such as personality inventories and make more objective decisions by anticipating their expectations from the candidate, to what extent the candidate can meet the needs of the enterprise and the potential drawbacks should be considered as a recommendation.

In this context, conducting studies on the relationships between psychological capital, personality and organizational commitment in different sectors and in a way to include both white-collar employees and blue-collar employees will provide significant contributions to the scientific field and practice.

The fact that the concepts constituting the subject of this study were discussed with their sub-components, the use of sampling methods that can be generalized by studying with wider samples through different sectors and businesses, and the evaluation of results are considered to be important contributions to the literature. However, it is particularly important to carry out these studies along with focus group studies at the level of managers and employees by considering the fact that qualitative studies, as well as quantitative studies, provide significant scientific information.

\section{References}

Ahmadi, A.A., Shahbazi, M., \& Hashemian, N. (2015). Relationship of Psychological Capital and Organizational Commitment of Employees in Payame Noor University. International Journal of Review in Life Sciences, 5(1), 868-874.

Ahmadi, S.A., Ardi, S.Z., Zare, R., \& Fathizadel, A.R. (2012). Effect of personality characteristic on organizational commitment and job performance. Journal of American Science, 8(1), 321-326.

Allen, N.J., \& Meyer, J.P. (1990). The measurement and antecedents of affective, continuance and normative commitment to the organization. Journal of Occupational Psychology, 63, 1-18. https://doi.org/10.1111/j.2044-8325.1990.tb00506.x

Allen, N.J., \& Meyer, J.P. (1996). Affective, Continuance, and Normative Commitment to the Organization: An Examination of Construct Validity. Journal of Vocational Behavior, 49(3), 252-276. https://doi.org/10.1006/jvbe.1996.0043

Avey, J.B., Luthans, F., \& Jensen, S.M. (2009). Psychological Capital: A Positive Resource For Combating Employee Stress and Turnover. Human Resource Management, 48(5), 677-693. https://doi.org/10.1002/hrm.20294

Avey, J.B., Luthans, F., \& Youssef, C.M. (2010). The Additive Value of Positive Psychological Capital in Predicting Work Attitudes and Behaviors. Journal of Management, 36(2), 430-452. https://doi.org/10.1177/0149206308329961

Avey, J.B., Reichard, R.J., Luthans, F., \& Mhatre, K.H. (2011). Meta-Analysis of the Impact of Positive Psychological Capital on Employee Attitudes, Behaviors, and Performance. Human Resource Development Quarterly, 22(2), 127-152. https://doi.org/10.1002/hrdq.20070

Barrick, M.R., \& Mount, M.K. (1991). The Big Five personality dimensions and job performance: A meta-analysis. Personnel Psychology, 44(1), 1-26. https://doi.org/10.1111/j.1744-6570.1991.tb00688.x

Barrick, M.R., Mount, M.K., \& Judge, T.A. (2001). Personality and performance at the beginning of the new millennium: What do we know and where do we go next?. International Journal of Selection and Assessment, 9(1-2), 9-30. https://doi.org/10.1111/1468-2389.00160 
Benet-Martínez, V., \& John, O.P. (1998). Los Cinco Grandes across cultures and ethnic groups: Multitrait-multimethod analyses of the Big Five in Spanish and English. Journal of Personality and Social Psychology, 75(3), 729-750. https://doi.org/10.1037/0022-3514.75.3.729

Brandt, T., Gomes, J.F., \& Boyanova, D. (2011). Personality and psychological capital as indicators of future job success?. Liiketaloudellinen Aikakauskirja, 3, 263-289.

Burger, J.M. (2006). Kişilik. İ. D. Erguvan Sarıŏlu (çev.). İstanbul: Kaknüs Yayınları.

Cetin, F. (2011). The effects of the organizational psychological capital on the attitudes of commitment and satisfaction: A public sample in Turkey. European Journal of Social Sciences, 21(3), 373-380. https://doi.org/10.4026/1303-2860.2011.0184.x

Cetin, F., \& Basim, H.N. (2012). Örgütsel Psikolojik Sermaye: Bir Ölçek Uyarlama Çalışması. Amme İdaresi Dergisi, 45(1), 121-137.

Cetin, M. (2015). Individual and Organizational Antecedents of Psychological Capital. Yayınlanmamış Doktora Tezi, İstanbul: Marmara Üniversitesi Sosyal Bilimler Enstitüsü.

Costa, P.T., \& McCrae, R.R. (1992). Professional manual for the NEO PI-R. Odessa, FL: Psychological Assessment Resources.

Cuceloglu, D. (2012). İnsan ve Davranışl: Psikolojinin Temel Kavramları. 25. Basım. İstanbul: Remzi Kitabevi.

Darbanyan, M., Samavatyan, H., Oreyzi, H.R., \& Mousavirad, S.M. (2014). Simple and Multiple Relationships between the Five Factor Model of Personality and Organizational Commitment. Advances in Natural and Applied Sciences, 8(14), 12-17.

Diržytė, A., Patapas, A., Smalskys, V., \& Udavičıūtė, V. (2013). Relationship between Organizational Commitment, Job Satisfaction, and Positive Psychological Capital in Lithuanian Organizations. International Journal of Business and Social Science, 4(12), 115-122.

Eid, J., Mearns, K., Larsson, G., Laberg, J.C., \& Johnsen, B.H. (2012). Leadership, psychological capital and safety research: Conceptual issues and future research questions. Safety Science, 50, 55-61. https://doi.org/10.1016/j.ssci.2011.07.001

Etebarian, A., Tavakoli, S., \& Abzari, M. (2012). The relationship between psychological capital and organizational commitment. African Journal of Business Management, 6(14), 5057-5060. https://doi.org/10.5897/AJBM11.2844

Hackney, C.W. (2012). Personality, organizational commitment, and job search behavior: A field study. Doctoral Dissertation. University of Tennessee.

Kappagoda, S. (2013). The impact of five-factor model of personality on organizational commitment of English teachers in Sri Lankan Government Schools, 1-10. Retrieved from http://papers.ssrn.com/sol3/papers.cfm?abstract_id=2220719

Khoeini, F., \& Attar, B.N. (2015). Personality characteristics and organizational commitment in Iranian employees. International Journal of Scientific $\quad$ Reports, $\quad 1(1), \quad 61-64$. https://doi.org/10.18203/issn.2454-2156.IntJSciRep20150203

Kilic, R., \& Bozkaya, E. (2014). Örgüt Çalışanlarının Kişilik Özellikleri İle Örgütsel Bağlılıkları Arasındaki İlişkinin İncelenmesi. Süleyman Demirel Üniversitesi Sosyal Bilimler Enstitüsü Dergisi, Sayl, 20, 153-178.

Kumar, K., \& Bakhshi, A. (2010). The Five-factor Model of Personality and Organizational Commitment: Is There Any Relationship. Humanity and Social Sciences Journal, 5(1), 25-34.

Lather, A.S., \& Kaur, M.S. (2015). Psychological Capital as Predictor of Organizational Commitment and Organizational Citizenship Behavior. The International Journal of Indian Psychology, 2(4), 102-112.

Lifeng, Z. (2007). Effects of Psychological Capital on Employees' Job Performance, Organizational Commitment, and Organizational Citizenship Behavior. Acta Psychologica Sinica, 39(2), 328-334.

Luthans, F., \& Youssef, C.M. (2004). Human, Social, and Now Positive Psychological Capital Management: Investing in People for Competitive Advantage. Organizational Dynamics, 33(2), 143-160. https://doi.org/10.1016/j.orgdyn.2004.01.003 
Luthans, F., \& Youssef, C.M. (2007). Emerging Positive Organizational Behavior. Journal of Management, 33(3), 321-349. https://doi.org/10.1177/0149206307300814

Luthans, F., Avey, J.B., Avolio, B.J., Norman, S.M., \& Combs, G.M. (2006). Psychological capital development: toward a micro-intervention. Journal of Organizational Behavior, 27, 387-393. https://doi.org/10.1002/job.373

Luthans, F., Avolio, B.J., Avey, J.B., \& Norman, S.M. (2007). Positive Psychological Capital: Measurement and Relationship with Performance and Satisfaction. Personnel Psychology, 60, 541-572. https://doi.org/10.1111/j.1744-6570.2007.00083.x

Luthans, F., Luthans, K.W., \& Luthans, B.C. (2004). Positive psychological capital: Beyond human and social capital. Business Horizons, 47(1), 45-50. https://doi.org/10.1016/j.bushor.2003.11.007

Luthans, F., Norman, S.M., Avolio, B.J., \& Avey, J.B. (2008). The mediating role of psychological capital in the supportive organizational climate-employee performance relationship. Journal of Organizational Behavior, 29, 219-238. https://doi.org/10.1002/job.507

Luthans, F., Youssef, C.M., \& Avolio, B.J. (2007). Psychological Capital: Developing the Human Competitive Edge. USA: Oxford University Press.

Meyer, J.P., \& Allen, N.J. (1991). A three-component conceptualization of organizational commitment. Human Resource Management Review, 1(1), 61-89. https://doi.org/10.1016/1053-4822(91)90011-Z

Meyer, J.P., \& Allen, N.J. (1997). Commitment in the workplace: Theory, research and application. Sage Publications, Inc.

Meyer, J.P., Allen, N.J., \& Smith, C.A. (1993). Commitment to organizations and occupations: Extension and test of a three-component conceptualization. Journal of Applied Psychology, 78(4), 538-551. https://doi.org/10.1037/0021-9010.78.4.538

Morgan, C.F. (2011). Psikolojiye Giriş. S. Karakaş \& R. Eski (Ed.). 19. Basım. Konya: Eğitim Akademi.

Morrow, P.C., \& McElroy, J.C. (1986). On assessing measures of work commitment. Journal of Organizational Behavior, 7(2), 139-145. https://doi.org/10.1002/job.4030070206

Mowday, R.T., Porter, L.W., \& Steers, R.M. (1982). Employee-organization linkages: The psychology of commitment, absenteeism, and turnover. Academic Press.

Mowday, R.T., Steers, R.M., \& Porter, L.W. (1979). The Measurement of Organizational Commitment. Journal of Vocational Behavior, 14(2), 224-247. https://doi.org/10.1016/0001-8791(79)90072-1

Ocak, M., Guler, M., \& Basim, H.N. (2016). Psikolojik Sermayenin Örgütsel Bağllılı ve İş Tatmini Tutumları Üzerine Etkisi: Bosnalı Öğretmenler Üzerine Bir Araştırma. Çankırı Karatekin Üniversitesi İ̈BF Dergisi, Cilt 6, Say1 1, 113-130. https://doi.org/10.18074/cnuiibf.274

Plotnik, R. (2009). Psikolojiye Giriş. T. Geniş (çev.). İstanbul: Kaknüs Yayınları.

Recepoglu, E., Kilinc, A.C., Sahin, F., \& Er, Emre (2013). Öğretim Elemanlarının Kişilik Özellikleri İle Örgütsel Bağlılık Düzeyleri Arasındaki İlişki. Turkish Studies - International Periodical For The Languages, Literature and History of Turkish or Turkic, 8(6), 603-617. https://doi.org/10.7827/TurkishStudies.4877

Robbins, S.P., \& Judge, T.A. (2013). Örgütsel Davranış. 14. Basımdan Çeviri. İ. Erdem (çev. ed.). Ankara: Nobel Akademik Yayıncilı.

Ryckman, R.M. (2008). Theories of Personality. Ninth Edition. Thomson Wadsworth, USA.

Sadeghi, P., \& Yazdanbakhsh, K. (2014). The Relationship between the Big Five Personality Factors and the Willingness and Organizational Commitment of Teachers. Applied mathematics in Engineering, Management and Technology, 2(5), 28-36.

Sahoo, B.C., \& Sia, S.K. (2015). Psychological Capital and Organisational Commitment: Nature, Structure and Relationship in an Indian Sample. Asia-Pacific Journal of Management Research and Innovation, 11(3), 230-244. https://doi.org/10.1177/2319510X15588386

Saydan, R., \& Sututemiz, N. (2009). Tüketici Etnosentrizmi Etkisini Ölçmede CETSCALE Ölçeği. Finans Politik \& Ekonomik Yorumlar, Cilt 46, Say1 534, 77-91. 
Schmitt, D.P., Allik, J., McCrae, R.R., \& Benet-Martínez, V. (2007). The geographic distribution of Big Five personality traits patterns and profiles of human self-description across 56 nations. Journal of cross-cultural psychology, 38(2), 173-212. https://doi.org/10.1177/0022022106297299

Sharifi, N., \& Shahtalebi, B. (2014). The Relationship Between Dimensions of Psychological Capital With Organizational Commitment Studied: Staffs of General Directorate of Education of Isfahan. Kuwait Chapter of the Arabian Journal of Business and Management Review, 3(11a), 23-30. https://doi.org/10.12816/0018777

Simons, J.C., \& Buitendach, J.H. (2013). Psychological capital, work engagement and organisational commitment amongst call centre employees in South Africa. SA Journal of Industrial Psychology/SA Tydskrif vir Bedryfsielkunde, 39(2), 1-12. https://doi.org/10.4102/sajip.v39i2.1071

Somer, O. (1998). Türkçe'de Kişilik Özelliği Tanımlayan Sıfatların Yapısı ve Beş Faktör Modeli. Türk Psikoloji Dergisi, 13(42), 17-32.

Tanriverdi, H. (2012). Kişilik Özelliklerinin İş Değerlerine ve Örgütsel Bağlllık Üzerine Etkisi: Hastane Çalışanları Üzerinde Bir Araştırma. Türkiye Sosyal Araştırmalar Dergisi, 16(2), 189-210.

Totawar, A.K., \& Nambudiri, R. (2014). How does Organizational Justice influence Job Satisfaction and Organizational Commitment? Explaining with Psychological Capital. Vikalpa, 39(2), 83-97. https://doi.org/10.1177/0256090920140209

Wang, M., \& Erdheim, J. (2007). Does the five-factor model of personality relate to goal orientation?. Personality and Individual Differences, 43(6), 1493-1505. https://doi.org/10.1016/j.paid.2007.04.024

Wasti, S.A. (2000). Meyer ve Allen'in Üç Boyutlu Örgütsel Bağllılk Ölçeğinin Geçerlilik ve Güvenilirlik Analizi. 8. Ulusal Yönetim ve Organizasyon Kongresi Bildiriler Kitabl, 401-410.

Wayne, J.H., Musisca, N., \& Fleeson, W. (2004). Considering the role of personality in the work-family experience: Relationships of the big five to work-family conflict and facilitation. Journal of Vocational Behavior, 64, 108-130. https://doi.org/10.1016/S0001-8791(03)00035-6

Yazgan Inanc, B., \& Yerlikaya, E.E. (2013). Kişilik Kuramları. 7. Basım. Ankara: Pegem Akademi.

Youssef-Morgan, C.M. (2014). Advancing OB Research: An Illustration Using Psychological Capital. Journal of Leadership \& Organizational Studies, 21(2), 130-140. https://doi.org/10.1177/1548051813515512

\section{Note}

This study was prepared using the Doctoral thesis presented to Sakarya University Institute of Social Sciences. 